\title{
Growth of black pepper plantlets under different substrates and irrigation levels
}

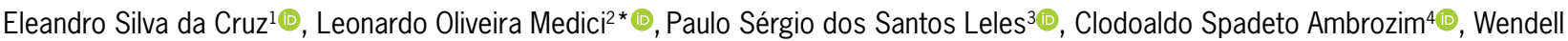 \\ Luccas Souza ${ }^{4}$, Daniel Fonseca de Carvalho ${ }^{4}$
}

1 Instituto Nacional de Colonização e Reforma Agrária, Av. Senador Robert Kennedy, 601 - 29114-300 - Vila Velha, ES - Brasil.

2Universidade Federal Rural do Rio de Janeiro/Instituto de Ciências Biológicas e da Saúde - Depto. de Ciências Fisiológicas, Rod. BR 465, km 7 - 23897-000 - Seropédica, RJ - Brasil.

3Universidade Federal Rural do Rio de Janeiro/Instituto de Florestas - Depto. de Silvicultura, Rod. BR 465, km 7 23897-000 - Seropédica, RJ - Brasil.

${ }^{4}$ Universidade Federal Rural do Rio de Janeiro/Instituto de Tecnologia - Depto. de Engenharia, Rod. BR 465, km 7 23897-000 - Seropédica, RJ - Brasil.

*Corresponding author <Imedici@gmail.com>

Edited by: Mohammad Bagher Hassanpouraghdam

Received April 04, 2020

Accepted July 24, 2020
ABSTRACT: Optimization of the use of water and the possibility of using residues as substrate in the black pepper production chain can yield economic and environmental benefits. The objective of this study was to evaluate the biometric and physiological traits of black pepper plantlets (Piper nigrum L.), cv. Bragantina, at different irrigation levels and soilless substrates. Plantlets were grown for 120 days on three substrates [biosolid + crushed coconut fiber (3:1, by volume); biosolid + granitic rock powder ( $3: 1$, by volume); and biosolid + crushed coconut fiber + granitic rock powder (2:1:1, by volume)] and at five irrigation levels [36 \% (very low); $55 \%$ (low); $85 \%$ (moderate); $100 \%$ (well-irrigated); and $126 \%$ of the reference irrigation level (over-irrigated)]. The biometric traits evaluated increased as the irrigation levels increased, with the exception of root dry mass, which was not influenced by this factor, nor water use efficiency, which decreased as the irrigation levels increased. In general, plants grown with a mixture of the three wastes (biosolid + crushed coconut fiber + granitic rock powder) exhibited higher values for biometric variables and chlorophyll content when they were moderately, well or over-irrigated, in comparison with the other two substrates. It was possible to achieve the plantlet commercial standard using this three waste mixture and the moderate irrigation level.

Keywords: Piper nigrum L., deficit irrigation, potting mix, biosolid, granitic rock powder

\section{Introduction}

Black pepper (Piper nigrum L.) is a vine widely used in the pharmaceutical, cosmetic and food industries (Takoore et al., 2019), which justifies its economic importance. Brazilian production is among the five most important in the world $(\mathrm{FAO}, 2018)$, despite the fact that Brazilian farmers face several diseases throughout the country, as well as the lack of water availability in parts of the main production regions. Root rot disease caused by the soil fungus Fusarium solani (Mart.) Sacc. f. sp. piperis Albuq. (Albuquerque and Ferraz, 1976) is the most important, since it can lead to the demise of entire plantations. Because there is no effective chemical control or resistant cultivar registered in Brazil (Benchimol et al., 2017), its control must be based on preventive actions, such as the use of healthy plantlets, which can be produced on substrates free from sources of phytopathogen propagation.

In this respect, waste has the potential to be used as substrates in nurseries, which can also result in environmental benefits, and prevent the inappropriate disposal of these materials in the environment (Sharma et al., 2017). However, its chemical and physical characteristics, costs and availability must be considered too (Schindler and Müller, 2017); otherwise its use is economically unfeasible. Studies have demonstrated the feasibility of several types of alternative materials as components of substrates for plants including: agroindustrial residues (Abad et al., 2005; Fermino et al., 2018), biosolid (Abreu et al., 2017) and granitic rock powder (Paradelo et al., 2016), but rare are those that deal with the use for the production of black pepper plantlets.

The seedling and plantlet production systems are also affected by the availability of water which requires its more efficient use and the recycling of run-off in nurseries (Beeson Jr. et al., 2004). Despite the importance of black pepper to Brazilian agriculture, there are no studies relating to the crop water requirement under tropical conditions, especially in the plantlet phase.

The objective of this study was to evaluate the effects of different irrigation levels (IL) and soilless substrates on the biometric and physiological traits of black pepper plantlets (Piper nigrum L.), cv. Bragantina.

\section{Material and Methods}

\section{Study conditions description}

The experiment was conducted between Mar and July 2018, in an East-West facing greenhouse, located in the metropolitan region of the state of Rio de Janeiro, Brazil, using black pepper plantlets, cv. Bragantina. During the experiment, the greenhouse's control system was adjusted to cool the environment whenever the temperature reached $30{ }^{\circ} \mathrm{C}$, lowering it to $28{ }^{\circ} \mathrm{C}$. To monitor the experimental climatic conditions, a weather station was installed inside the greenhouse. The daily temperature and relative humidity data are shown in Figure 1A while solar radiation and photosynthetically active radiation (PAR) data are shown in Figure 1B. 


\section{Treatments and experimental design}

The experimental design was completely randomized in a $3 \times 5$ (substrates $\times$ IL) factorial scheme with ten replicates. Plantlets were grown for 120 days on three substrates $[\mathrm{BC}=$ bissolid + crushed coconut fiber $\mid 3: 1$, by volume); $\mathrm{BG}=$ biosolid + granitic rock powder $(3: 1$, by volume); and BCG = biosolid + crushed coconut fiber + granitic rock powder $(2: 1: 1$, by volume)] and five irrigation levels [36 \% (very low); $55 \%$ (low); $85 \%$ (moderate); $100 \%$ (well-irrigated); and $126 \%$ (overirrigated) with IL reference (RIL)]. Water was applied at flow rates of 1.4 (very low), 2.1 (low), 3.3 (moderate), 3.9 (well-irrigated) and $4.9 \mathrm{~L} \mathrm{~h}^{-1}$ (over-irrigated).
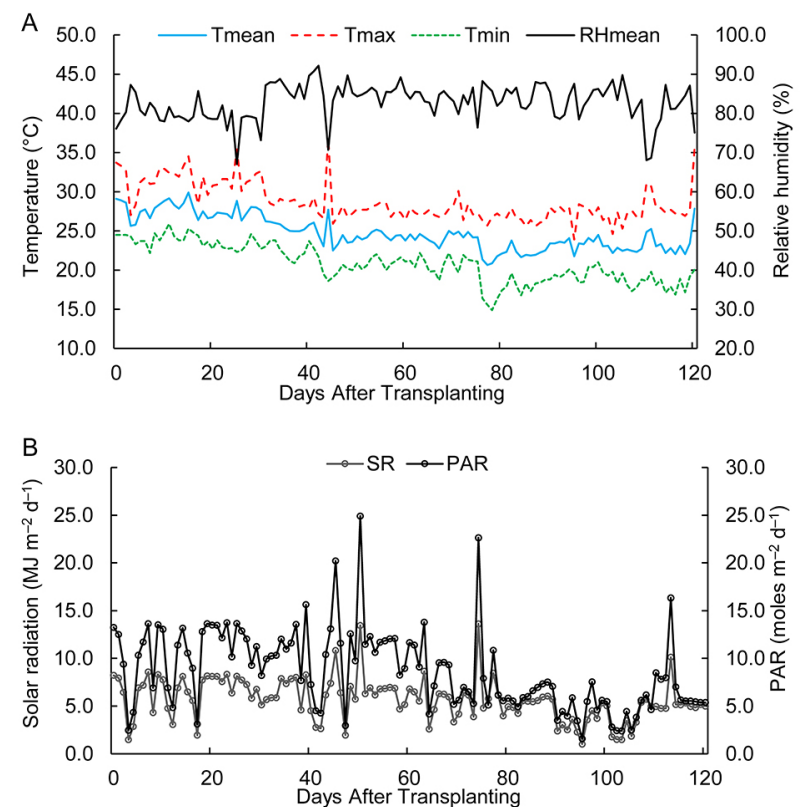

Figure 1 - Daily values of minimum, mean and maximum temperatures, mean relative humidity $(A)$ and daily accumulated values of solar radiation (SR) and photosynthetically active radiation $[P A R](B)$ recorded inside the greenhouse throughout the experimental period.

\section{Plantlet production}

The plantlets were obtained by a rooting process of single-node leafy stem cuttings collected from threeyear-old plants in a property located in São Mateus county (18 $43^{\prime} 49^{\prime \prime} \mathrm{S}, 40^{\circ} 14^{\prime} 11^{\prime \prime} \mathrm{W}$, altitude of $\left.117 \mathrm{~m}\right)$ in the northern region of the state of Espírito Santo, Brazil for 60 days in a sand medium. Before planting in the sand medium, the cuttings were immersed in a fungicide solution based on carbendazim $(2 \mathrm{~g}$ c.p. $\mathrm{L}^{-1}$ ) for $5 \mathrm{~min}$, dried in the shade for $30 \mathrm{~min}$, and subjected to basal application of indole-butyric acid diluted to $5.0 \mathrm{~g} \mathrm{~kg}^{-1}$ of inert powder (Secundino et al., 2014).

\section{Transplantings}

On Mar 5, 2018, the plantlets were transferred to 280- $\mathrm{cm}^{3}$ tubes, filled with the substrates, which were arranged on plastic trays in such a way that the planting density was equal to 68 plants per $\mathrm{m}^{2}$. At the time of transplanting, the humidity of the substrates was standardized, rising to the capacity of the container, by applying water manually.

The biosolid used was provided by the Rio de Janeiro state Water and Sewage Company (CEDAE) and is obtained by the stabilization of the sludge produced during the sewage treatment process at the sewage treatment plant located in Ilha do Governador, in the municipality of Rio de Janeiro. The crushed coconut fiber was a commercial product normally recommended for the sowing of coffee and vegetables and production of clonal eucalyptus plantlets. The granitic rock powder was provided by an ornamental rock industrial plant located in Vargem Alta county $\left(20^{\circ} 40^{\prime} 16^{\prime \prime} \mathrm{S}, 41^{\circ} 00^{\prime} 27^{\prime \prime} \mathrm{W}\right.$, altitude $\left.596 \mathrm{~m}\right)$, in the state of Espírito Santo, Brazil. This powder comes from the primary processing of granite blocks by the gang saw method using abrasive solution.

Table 1 shows the bioavailable chemical properties, volumetric density on dry basis and total porosity of the formulated substrates.

Table 1 - Chemical and physical properties of substrates used in the cultivation of black pepper plantlets.

\begin{tabular}{|c|c|c|c|c|c|c|c|c|}
\hline SUBS & $\mathrm{pH}\left(\mathrm{H}_{2} \mathrm{O}\right)$ & EC & $\mathrm{N}^{*}$ & $\mathrm{P}$ & $\mathrm{K}^{+}$ & $\mathrm{Ca}^{2+}$ & $\mathrm{Mg}^{2+}$ & $\mathrm{Na}^{+}$ \\
\hline & & $\mathrm{mS} \mathrm{cm}^{-1}$ & \multicolumn{2}{|c|}{$\mathrm{mg} \mathrm{dm}^{-3}$} & - & - & $n^{-3}$ & - \\
\hline $\mathrm{BC}$ & 3.9 & 1.6 & 26.0 & 36.1 & 1.1 & 11.5 & 1.2 & 0.4 \\
\hline$B G$ & 5.4 & 2.0 & 16.3 & 27.4 & 0.9 & 15.1 & 0.8 & 0.4 \\
\hline BCG & 4.6 & 1.8 & 13.2 & 25.9 & 1.0 & 14.4 & 0.7 & 0.4 \\
\hline \multirow[t]{2}{*}{ SUBS } & $\mathrm{Al}^{3+}$ & $\mathrm{H}^{+}+\mathrm{Al}^{3+}$ & $\mathrm{S}$ & CEC & $\mathrm{T}$ & V & Ds & TP \\
\hline & \multicolumn{4}{|c|}{$\left.-\mathrm{cmol}_{\mathrm{c}} \mathrm{dm}^{-3}\right)-$} & - & $\%$ & $\mathrm{~g} \mathrm{~cm}^{-3}$ & $\%$ \\
\hline$B C$ & 0.3 & 11.2 & 14.1 & 14.4 & 25.7 & 55.8 & 0.64 & 61.4 \\
\hline$B G$ & 0.00 & 4.3 & 17.3 & 17.3 & 21.5 & 80.1 & 0.77 & 63.0 \\
\hline BCG & 0.00 & 5.1 & 16.5 & 16.5 & 21.6 & 76.5 & 0.53 & 72.9 \\
\hline
\end{tabular}

SUBS = substrates; $B C=$ biosolid (BS) + crushed coconut fiber (CF) (3:1, by vol.); $B G=B S+$ granitic rock powder (GR) (3:1, by vol.); $B C G=B S+C F+G R(2: 1: 1$, by vol.); $\mathrm{EC}=$ electrical conductivity; $\mathrm{S}=$ sum of exchangeable bases; $\mathrm{CEC}=$ Effective cation exchange capacity; $\mathrm{T}=$ total cation exchange capacity; $\mathrm{V}=$ base saturation percentage; Ds = volumetric density; TP = total porosity; ${ }^{\star}$ total Kjeldahl N. 


\section{Irrigation management}

Shortly after transplanting, the ILs were started through a drip irrigation system operated at a pressure of 60 $\mathrm{kPa}$. According to the test performed, Christiansen's uniformity coefficient was equal to $96.0 \%$ and the distribution uniformity coefficient was equal to $93.9 \%$.

Irrigation management was carried out automatically at $4 \mathrm{kPa}$ through the installation of simplified irrigation controllers (Medici et al., 2010) in two reference plants which were grown in the BC substrate and were well-irrigated. The porous capsule used as an irrigation controller sensor was made from domestic water filter candles in such a way that the dimensions were reduced (Bezerra et al., 2019) so as to enable installation in the tubes. Thus, the plants' water requirement was taken into consideration when defining RIL, facilitating the establishment of the ILs tested.

The volume of water applied per treatment over time was estimated from daily readings of an analogical water meter installed on the main line of the irrigation system. There were 27 automatic actuations of the irrigation system which applied a total of 0.282 (very low), 0.424 (low), 0.666 (moderate), 0.787 (wellirrigated), and $0.988 \mathrm{~L}$ of water per plant (over-irrigated).

\section{Data collection and analysis}

Main stem height $(\mathrm{H})$, number of leaves (NL), shoot (stem + leaves) and root system dry masses (SDM and RDM, respectively), leaf area index (LAI) and chlorophylls a (CHLa) and $b$ (CHLb) contents were evaluated at 120 days after transplanting (DAT). H and NL were measured directly prior to harvest based on a cut close to the substrate surface. Chlorophyll measurements were also taken before harvest, using a portable chlorophyll meter (Falker Automação Agrícola Ltda., Porto Alegre county, in the state of Rio Grande do Sul - Brazill, sampling three plants per treatment, randomly chosen before the beginning of the experiment. Three measurements were taken at different points on each leaf which were always the newest and fully expanded ones on each plant.

Immediately after harvest, all fully expanded leaves of each plant were collected to determine the areas in a leaf area meter which made it possible to determine LAI. The plants were then divided into stem and root systems which, together with the leaves, were dried in a forced circulation oven for $72 \mathrm{~h}$ and then weighed on an analytical scale to determine SDM (stem + leaves) and RDM. Water use efficiency (WUE), in kg $\mathrm{m}^{-3}$, was calculated as the relationship between total dry mass production (SDM + RDM), in $\mathrm{kg}$, and the total volume of water applied in each IL $\left(\mathrm{m}^{3}\right)$.

\section{Statistical analysis}

The normality and equality of variances of residuals were assessed by the Shapiro-Wilk test and Bartlett's test, respectively, at a $5 \%$ probability level. According to the results, the traits NL, LAI, RDM and WUE were transformed to $\sqrt{x}$.

The analysis of variance was performed by the F-test $(p<0.05)$ for all traits evaluated.

After rejecting the null hypothesis, regression analyses were performed with linear and quadratic regression models charting all traits against ILs except for RDM as this trait was not significantly affected ( $p>0.05$, F-test) by ILs. For the traits LAI, NL, CHLa and CHLb interaction between substrates and ILs was significant ( $p<0.05, \mathrm{~F}$-test). In these cases, the regression analysis was sliced in each substrate.

The regression models were analyzed using the minimal squares method by matrix algebra (Ferreira, 2019). The significance of the models coefficients was tested by t-test $(p<0.05$ and $p<0.01)$. The best models were chosen considering the higher determination $\left(\mathrm{R}^{2}\right)$ and adjusted determination coefficients $\left(\mathrm{R}_{a d j}^{2}\right)$ in addition to the lower significance level of the models' coefficients by the t-test and non-residual significance by the F-test $(p>0.05)$.

For the substrate factor, Tukey's means comparison test was performed with a $5 \%$ significance level.

All statistical analyses in this study were conducted using the $\mathrm{R}$ software package, version 3.6.0, and Sisvar software, version 5.6.

\section{Results and Discussion}

The traits H, SDM and WUE were influenced by the ILs regardless of the substrates (Figures 2 and 5). The substrates, in turn, influenced the values of $\mathrm{H}$ and RDM regardless of the ILs (Table 2). The traits LAI (Figure 3A), NL (Figure 3B), CHLa (Figure 4A) and $\mathrm{CHLb}$ (Figure 4B) were affected by the interaction between both factors.

There were positive responses of $\mathrm{H}$ and SDM as a function of the increase in ILs in all substrates. The $\mathrm{H}$ values ranged from 11.8 to $20.3 \mathrm{~cm}$, and increased at a rate of 1:10; thus an increment of 1 unit in $\mathrm{H}$ required a $10 \%$ increase in IL, while the increase of each gram of SDM was promoted by the increase of approximately $74 \%$ in the percentage of RIL which ranged from 1.3 (very low irrigation) to $2.6 \mathrm{~g}$ per plant (over irrigation) (Figure 2).

Table 2 - Mean and standard deviation of main stem height and root system dry mass of black pepper plantlets, cv. Bragantina, at 120 days after transplanting as a function of three soilless substrates.

\begin{tabular}{|c|c|c|c|}
\hline Characteristics & $\mathrm{BC}$ & BG & BCG \\
\hline Main Stem Height $(\mathrm{cm})$ & $16.4 \pm 4.7 b^{*}$ & $16.0 \pm 6.1 b$ & $18.9 \pm 7.3 a$ \\
\hline Root Dry Mass (g) & $0.23 \pm 0.13 b$ & $0.57 \pm 0.38 a$ & $0.45 \pm 0.22 \mathrm{a}$ \\
\hline
\end{tabular}
by Tukey's test $(p>0.05)$. 


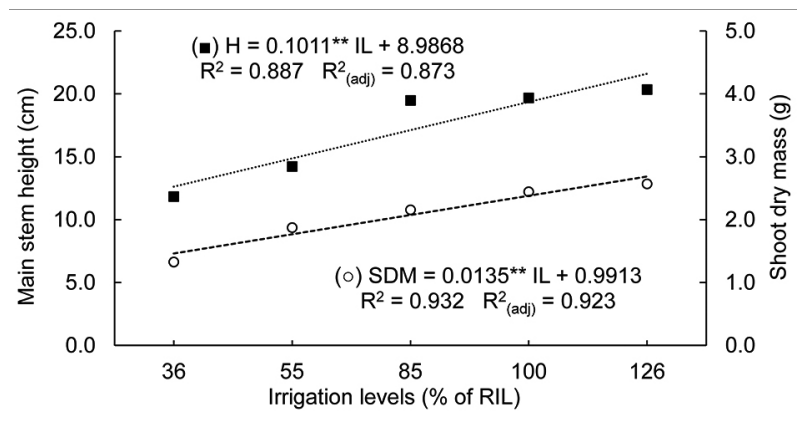

Figure 2 - Morphological characteristics of black pepper plantlets, cv. Bragantina, at 120 days after transplanting as a function of irrigation levels. $\mathrm{H}=$ Main stem height; $\mathrm{SDM}=$ shoot dry mass; $\mathrm{IL}=$ irrigation level; $\mathrm{RIL}=$ reference irrigation level; ${ }^{\star}$ * Significant coefficients by t-test $(p<0.01)$.
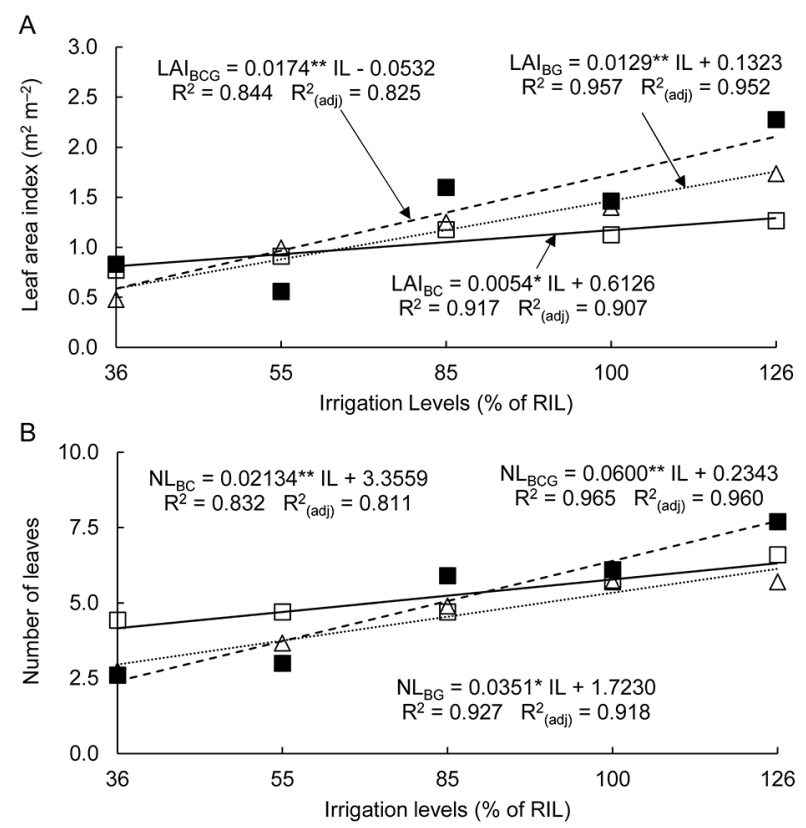

Figure 3 - Leaf area index (A) and number of leaves (B) of black pepper plants, cv. Bragantina, at 120 days after transplanting subjected to different substrates and irrigation levels. $L A l=$ leaf area index; $\mathrm{NL}=$ number of leaves; $\mathrm{RIL}=$ reference irrigation level; ( $\square$ ) BC = biosolid (BS) + crushed coconut fiber (CF) (3:1, by volume); $\triangle(\triangle) B G=B S+$ granitic rock powder (GR) (3:1, by vol.); and (ם) BCG = BS + CF + GR (2:1:1, by vol.). ${ }^{* *}$, ${ }^{*}$ Significant coefficients by t-test $(p<0.01$ and $p<0.05$, respectively) .

The increase in the values of $\mathrm{H}$ and SDM may be related to the reduction of stomatal resistance in plants satisfactorily supplied with water (Sezen et al., 2019), resulting in higher transpiration rates and assimilation of carbon dioxide, the latter being used in the photosynthesis process, generating products that are essential to plant development (Taiz et al., 2014).
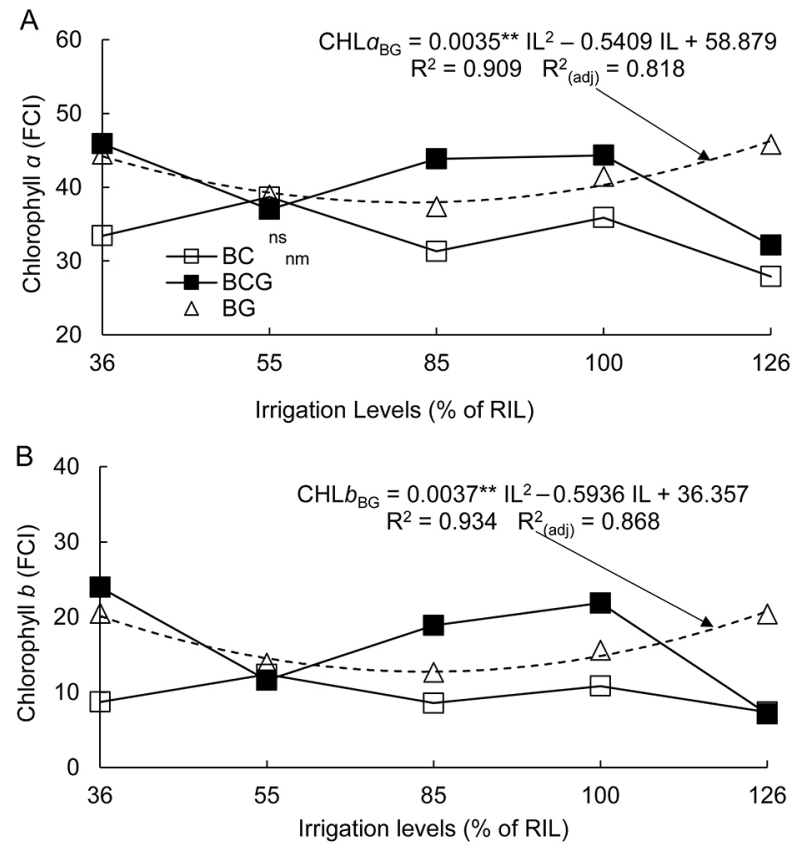

Figure 4 - Chlorophyll $a(A)$ and chlorophyll $b(B)$ indexes of black pepper plants, CV. Bragantina, subjected to different irrigation levels and soilless substrates, at 120 days after transplanting. $\mathrm{FCl}=$ Falker chlorophyll index; RIL = reference irrigation level; $(\square)$ $\mathrm{BC}=$ biosolid (BS) + crushed coconut fiber (CF) (3:1, by volume); $(\triangle) B G=B S+$ granitic rock powder (GR) (3:1, by vol.); and ( $\square$ ) $\mathrm{BCG}=\mathrm{BS}+\mathrm{CF}+\mathrm{GR}\left(2: 1: 1\right.$, by vol.). ${ }^{*}$ Significant coefficients by t-test $(p<0.01)$. ns Non-statistical difference between the means by F-test $(p>0.05)$. ${ }^{n m}$ Coefficients of linear and quadratic models non-significant by t-test ( $p>0.05)$.

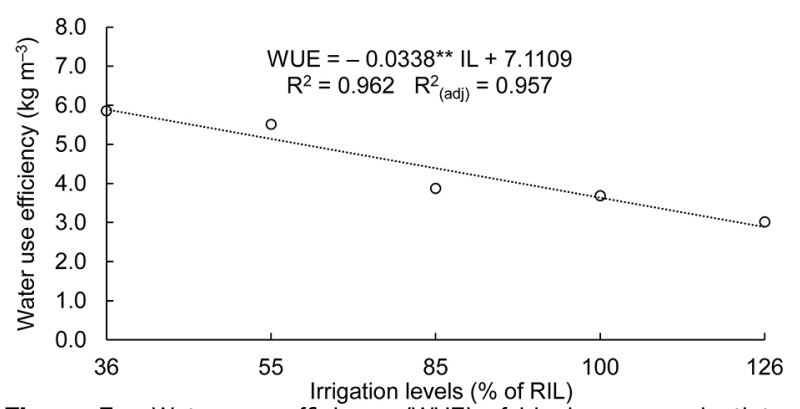

Figure $\mathbf{5}$ - Water use efficiency (WUE) of black pepper plantlets, cv. Bragantina, at 120 days after transplanting, as a function of irrigation levels. RIL $=$ Reference irrigation level. ${ }^{*}$ Significant coefficient by t-test $(p<0.01)$.

Regardless of the ILs, the highest $H$ value (18.9) was observed in plants grown with BCG while the highest RDM value $(0.57 \mathrm{~g})$ was observed in plants submitted to BG, followed by BCG (0.45 g) (Table 2).

The most positive responses of plants submitted to $\mathrm{BCG}$ and $\mathrm{BG}$, although $\mathrm{BC}$ has been defined as a standard substrate for irrigation purposes, may be associated with a phosphorus deficiency that occurred in 
$\mathrm{BC}$ since the $\mathrm{pH}$ of this substrate was equal to 3.9, with the presence of $0.30 \mathrm{cmol}_{\mathrm{c}} \mathrm{dm}^{-3}$ of $\mathrm{Al}^{+3}$ (Table 1). These conditions are favorable to the formation of aluminum phosphate which may make a considerable fraction of $\mathrm{P}$ unavailable. This deficiency can be identified by the root system, giving rise to a series of changes in plants, which leads to increases in remobilization and recycling of $\mathrm{P}$, reduction in photosynthetic rate, delay in shoot growth and reduction in the growth of lateral roots (Zhang et al., 2014).

There was an increase in LAI and NL according to the increase in IL in plants grown with all substrates tested. For both traits, the greatest variation occurred in the BCG substrate (increment of $0.17 \mathrm{~m}^{2} \mathrm{~m}^{-2}$ and 0.6 leaves, respectively, for each $10 \%$ increase in IL), in contrast to $\mathrm{BC}$, which had the smallest variation (increment of $0.05 \mathrm{~m}^{2} \mathrm{~m}^{-2}$ and 0.21 leaves, respectively) (Figure $3 \mathrm{~A}$ and $\mathrm{B}$ ).

Black pepper plantlets with $\mathrm{H}$ between 20 and $30 \mathrm{~cm}$ and six to eight leaves are considered suitable by Brazilian farmers for planting in the field (Serrano et al., 2012). According to these criteria, only plants moderately, well- or over-irrigated and cultivated using BCG had adequate $\mathrm{H}(21.6,22.0$ and $25.1 \mathrm{~cm}$, respectively) and NL (5.9, 6.1 and 7.7, respectively) (Figures 2 and 3B).

There was no significant effect ( $p>0.05$, by F-test) of ILs on CHLa and CHLb for BC. For BCG, there was no significance ( $p>0.05$, by t-test) of the adjustment of the linear or quadratic model. For BG substrate the variations in chlorophyll content followed a quadratic pattern. According to this fitted model, approximately $91 \%$ (CHLa) (Figure 4A) and $93 \%$ (CHLb) (Figure 4B) of the variation could be explained by the variation in the ILs. In this case, the highest values were found in very low- and over -irrigated plants. In the first case, there may have been a concentration of photosynthetic pigments in the leaves due to the fact that plants submitted to these treatments had low LAI values (Anjum et al., 2011; Valença et al., 2018). In the second case, the increase in indexes may be due to the relatively high quality development of plants, without suffering degradation, concentration or dispersion of chlorophyll.

With regard to plants grown using the BCG substrate, it is noteworthy that they had the highest chlorophyll contents under very low, moderate and well-irrigated conditions contrasting with the strong reduction experienced when they were overirrigated. This may be related to the dilution effect of photosynthetic pigments in the leaves due to the high leaf area that these plants exhibited (Figure 3A and B).

As for the chlorophyll content registered in plants cultivated with BC, in general they were low, with the smallest oscillations due to the ILs (Figure $4 \mathrm{~A}$ and $\mathrm{B}$ ). In this case, degradation of photosynthetic pigments may have occurred since plants subjected to stress due to lack of $\mathrm{P}$ (see discussion on Table 2) may have reduced photosynthetic rates (Zhang et al., 2014).
The generally higher values of biometric traits and chlorophyll content of plants grown with BCG and $\mathrm{BG}$, compared to $\mathrm{BC}$, even though the latter is defined as a reference for irrigation purposes, may be associated with the capacity of granitic rock powder for acid neutralization, supply of $\mathrm{Ca}$ and $\mathrm{Fe}$ (Barral Silva et al., 2005), and the capacity to increase water retention in the formulated substrates (Paradelo et al., 2016), conditions that favor the availability of nutrients to plants. In addition, due to the irrigation management adopted, depending on the water demand of plants cultivated with BC as previously discussed, provided unfavorable conditions for vegetative development, it is likely that the BG and BCG substrates did not express their full potential as a result of the reduction in water supply.

There was a negative linear relationship between ILs and WUE, and approximately $96 \%$ of the variation in WUE could be explained by the variation in ILs. A $10 \%$ reduction in the IL was equivalent to an increase of approximately $0.3 \mathrm{~kg}$ of total dry mass per cubic meter of supplied water. In absolute values, the highest WUE was found in very low irrigated plants $15.86 \mathrm{~kg}$ $\left.\mathrm{m}^{-3}\right)$. Compared to this IL, there were reductions of $5.9 \%$ (low irrigated), $33.9 \%$ (moderate), $37.1 \%$ (wellirrigated) and $48.5 \%$ (over-irrigated) in WUE values (Figure 5).

Although the two lowest ILs led to higher WUE values compared to the others, these levels also promoted the lowest values for $\mathrm{H}$, SDM (Figure 2), LAI (Figure 3A) and NL (Figure 3B). On the other hand, considering these same characteristics, except for SDM, small differences were observed in the values of moderately and well-irrigated plants. These results suggest that a deficit irrigation strategy of up to $15 \%$ during the stage of production of black pepper plantlets, cv. Bragantina, may be feasible as it does not cause significant changes in the quality of the plantlets produced (Figure 5). Similar results were obtained by Valença et al. (2018), who observed higher water use efficiency in lettuce plants grown in organic systems in pots when about $83 \%$ of the RIL was applied through a device similar to that employed in the present study.

Almost half of all Brazilian black pepper is produced in the state of Espírito Santo where plantations are concentrated in regions with water deficits close to $277 \mathrm{~mm}$ per year. In addition, this state produces approximately $34 \%$ of all Brazilian ornamental rocks, generating a large volume of waste which can cause serious environmental problems. On the other hand, only $41 \%$ of the sewage produced is collected and treated in Espírito Santo. Therefore, it is important to have options to use the waste especially in a scenario of increased sewage treatment in the state. Under this scenario, improvements in the use of water and residues in the black pepper production chain are important and can contribute to the competitiveness of the activity and environmental preservation in the region. 


\section{Conclusions}

Black pepper plantlets, cv. Bragantina, produced with the use of substrate produced by mixing biosolid, crushed coconut fiber and granitic rock powder, and irrigated with not less than $85 \%$ of the RIL, presented acceptable biometric traits.

\section{Acknowledgment}

This study was financed in part by the Coordination for the Improvement of Higher Level Personnel (CAPES) agency - Finance Code 001.

\section{Authors' Contributions}

Conceptualization: Cruz, E.S.; Carvalho, D.F.; Medici, L.O.; Leles, P.S.; Ambrozim, C.S. Data acquisition: Cruz, E.S.; Carvalho, D.F.; Ambrozim, C.S.; Santos, W.L. Data analysis: Cruz, E.S.; Carvalho, D.F.; Medici, L.O.; Ambrozim, C.S. Design of methodology: Cruz, E.S.; Carvalho, D.F.; Medici, L.O.; Leles, P.S.; Ambrozim, C.S.; Santos, W.L. Writing and editing: Cruz, E.S.; Carvalho, D.F.; Medici, L.O.

\section{References}

Abad, M.; Fornes, F.; Carrión, C.; Noguera, V.; Noguera, P.; Maquieira, A.; Puchades, R. 2005. Physical properties of various coconut coir dusts compared to peat. HortScience 40: 2138-2144.

Abreu, A.H.M.; Marzola, L.B.; Melo, L.A.; Leles, P.S.S.; Abel, E.L.S.; Alonso, J.M. 2017. Urban solid waste in the production of Lafoensia pacari seedlings. Revista Brasileira de Engenharia Agrícola e Ambiental 21: 83-87.

Albuquerque, F.C.; Ferraz, S. 1976. Morphological and physiological characteristics of Nectria haematococca f.sp. piperis and its pathogenicity to black pepper (Piper nigrum L.) = Características morfológicas e fisiológias de Nectria haematococca f.sp. piperis e sua patogenicidade à pimenta-doreino (Piper nigrum L.). Experientiae 22: 133-151 (in Portuguese).

Anjum, S.A.; Xie, X.; Wang, L.; Saleem, M.F.; Man, C.; Lei, W. 2011. Morphological, physiological and biochemical responses of plants to drought stress. African Journal of Agricultural Research 6: 2026-2032.

Barral Silva, M.T.; Silva Hermo, B.; García-Rodeja, E.; Vázquez Freire, N. 2005. Reutilization of granite powder as an amendment and fertilizer for acid soils. Chemosphere 61: 9931002.

Beeson Jr., R.C.; Arnold, M.A.; Bilderback, T.E.; Bolusky, B.; Chandler, S.; Gramling, H.M.; Lea-Cox, J.D.; Harris, J.R.; Klinger, P.J.; Mathers, H.M.; Ruter, J.M.; Yeager, T.H. 2004. Strategic vision of container nursery irrigation in the next ten years. Journal of Environmental Horticulturae 22: 113-115.

Benchimol, R.L.; Sutton, J.C.; Bastos, C.N.; Silva, C.M.; DiasFilho, M.B. 2017. By-products of Piper aduncum in the control of fusariosis in black pepper plant. Revista Brasileira de Ciências Agrárias 12: 303-308.
Bezerra, A.C.M.; Valença, D.C.; Carvalho, D.F.; Pinho, C.F.; Reinert, F.; Gomes, D.P.; Gabetto, F.P.; Azevedo, R.A.; Masseroni, D.; Medici, L.O. 2019. Automation of lettuce seedlings irrigation with sensors deployed in the substrate or at the atmosphere. Scientia Agricola 76: 179-189.

Fermino, M.H.; Araujo, M.M.; Aimi, S.C.; Turchetto, F.; Berghetti, Á.L.P.; Zavistanovicz, T.C.; Mieth, P.; Griebeler, A.M.; Vilella, J.M. 2018. Reutilization of residues as components of substrate for the production of Eucalyptus grandis seedlings. Cerne 24: 80-89.

Ferreira, D.F. 2019. SISVAR: a computer analysis system to fixed effects split plot type designs. Revista Brasileira de Biometria 37: 529-535.

Food and Agriculture Organization of the United Nations [FAO]. 2018. FAOStat. FAO, Rome, Italy. Available at: http://www.fao. org/faostat/en/\#data/QC [Accessed Jan 31, 2018]

Medici, L.O.; Rocha, H.S.; Carvalho, D.F.; Pimentel, C.; Azevedo, R.A. 2010. Automatic controller to water plants. Scientia Agricola 67: 727-730.

Paradelo, R.; Vázquez-Nion, D.; Silva, B.; González, Á.; Barral, M.T. 2016. Acidification of mixtures of granite powder and compost for reuse in plant production. Compost Science \& Utilization 24: 1-10.

Schindler, U.; Müller, L. 2017. Hydraulic Performance of horticultural substrates. 2. Development of an evaluation framework. Horticulturae 3: 1-6.

Secundino, W.; Alexandre, R.S.; Schmildt, E.R.; Schmildt, O.; Magevski, G.C.; Martins, J.P.R. 2014. Rhizogenic behavior of black pepper cultivars to indole-3-butyric acid. Acta Scientiarum-Agronomy 36: 355-364.

Serrano, L.A.L.; Marianto, F.A.; Magiero, M.; Sturm, G.M. 2012. Production of black pepper clonal cuttings in commercial substrate with controlled-release fertilizer. Revista Ceres 59: 512-517 (in Portuguese, with abstract in English).

Sezen, S.M.; Yazar, A.; Tekin, S. 2019. Physiological response of red pepper to different irrigation levels under drip irrigation in the Mediterranean region of Turkey. Scientia Horticulturae 245: 280-288.

Sharma, B.; Sarkar, A.; Singh, P.; Singh, R.P. 2017. Agricultural utilization of biosolids: a review on potential effects on soil and plant grown. Waste Management 64: 117-132.

Taiz, L.; Zeiger, E.; Møller, I.M.; Murphy, A. 2014. Plant Physiology and Development. Oxford University Press, New York, NY, USA.

Takoore, H.; Aumeeruddy, M.Z.; Rengasamy, K.R.R.; Venugopala, K.N.; Jeewon, R.; Zengin, G.; Mahomoodaly, M.F. 2019. A systematic review on black pepper (Piper nigrum L.): from folk uses to pharmacological applications. Critical Reviews in Food Science and Nutrition 59: 210-243.

Valença, D.C.; Carvalho, D.F.; Reinert, F.; Azevedo, R.A.; Pinho, C.F.; Medici, L.O. 2018. Automatically controlled deficit irrigation of lettuce in "organic potponics". Scientia Agricola 75: 52-59.

Zhang, Z.; Liao, H.; Lucas, W.J. 2014. Molecular mechanisms underlying phosphate sensing, signaling, and adaptation in plants. Journal of Integrative Plant Biology 56: 192-220. 